\title{
Modular Green Roofs for the Sustainability of the Built Environment: The Installation Process
}

\author{
Natalia Sergeevna Shushunova ${ }^{1, *}$, Elena Anatolyevna Korol ${ }^{1}$ and Nikolai Ivanovich Vatin ${ }^{2}$ (D) \\ 1 Moscow State University of Civil Engineering, 129337 Moscow, Russia; professorkorol@mail.ru \\ 2 Institute of Civil Engineering, Peter the Great St. Petersburg Polytechnic University, \\ 195251 St. Petersburg, Russia; vatin@mail.ru \\ * Correspondence: nshushun@gmail.com
}

Citation: Shushunova, N.S.; Korol, E.A.; Vatin, N.I. Modular Green Roofs for the Sustainability of the Built Environment: The Installation Process. Sustainability 2021, 13, 13749. https://doi.org/10.3390/ su132413749

Academic Editor:

Gianluca Scaccianoce

Received: 25 September 2021

Accepted: 7 December 2021

Published: 13 December 2021

Publisher's Note: MDPI stays neutral with regard to jurisdictional claims in published maps and institutional affiliations.

Copyright: (C) 2021 by the authors. Licensee MDPI, Basel, Switzerland. This article is an open access article distributed under the terms and conditions of the Creative Commons Attribution (CC BY) license (https:// creativecommons.org/licenses/by/ $4.0 /)$.

\begin{abstract}
The research object is the installation process of modular green roofs with planters placed on the concrete roof's surface. These roofs effectively reduce rainfall disposal, prolong the lifespan of the roof coating, and enhance urban aesthetic and recreational spaces. Green roofs reduce houses' gas emissions and increase green spaces in densely built areas. The spatial-technological model was developed for the proposed modular green roof based on network planning, scheduling theory, and graph theory. The sequence and composition of technological processes and operations were established for the installation process. The functional model of installing a modular green roof has been developed. The model makes it possible to optimise the principles of saving labour contribution (working hours) and time.
\end{abstract}

Keywords: green roof; technological processes; modular green roof; multiphysics models; living environment; green building technologies; greenhouse gas emissions

\section{Introduction}

Green roofs on buildings have multi-disciplinary benefits such as the improvement of rainfall disposal, the prolonged lifespan of the roof coating, the enhancement of urban aesthetic, and the creation of recreational spaces [1,2]. A quantitative analysis of 1623 English language sources indexed in Scopus from 1981 to 2020 shows that research on green roofs has steadily increased. Approximately $40.9 \%$ of the articles focus on regulating services in water, $30.0 \%$ on the thermal environment, and $3.5 \%$ on air quality [3]. Green roofs showed a surface temperature cooling effect [4,5]. The effects of urban heat islands [6] and global warming have led to an increased greening of cities as a tool for urban heat island mitigation in three main climate types: hot-humid, temperate, and dry [7-11]. Sustainability concerns have necessitated a shift towards sustainable urban water management systems, which could be analysed as multiphysics systems [12]. These systems include wet ponds, rain gardens, and green roofs [13]. Green roofs can contribute certain pollutants to rainfall disposal [14].

According to the 70th edition of Statistical Review of World Energy from British Petroleum in 2021 [15], the top five countries accounted for $59.4 \%$ of all $\mathrm{CO}_{2}$ emissions. The largest emitter was China, as its share was $30.7 \%$. The United States, with a share of $13.8 \%$, was in second place; India, with a share of $7.1 \%$, is in third place; Russia, with a share of $4.6 \%$, is in fourth place; and Japan, with a share of $3.2 \%$, is in fifth place. Therefore, it is necessary to establish full-fledged monitoring of this process on the planet.

The absorption of carbon dioxide could be achieved with an increase in green spaces in cities by creating green roofs and green walls on public buildings. Green roofs reduce houses' gas emissions and increase green spaces in densely built areas [16-21]. Another benefit of green roofs is that they offer new job opportunities; the larger the area, the more people are needed to design and maintain the roofing. Buildings with green roofs are 
more attractive to tenants and buyers, which means they can be rented out and sold at a higher rate [22].

Green roofs can be integrated with photovoltaics, providing additional benefits compared to the conventional green roof. The various challenges hinder the large-scale implementation of photovoltaic-green roofs, including high initial costs, limited experimental data, and lack of awareness about the long-term benefits [23].

There are two possible green roof technological design types: stationary and modular.

On a stationary green roof, the primary layers are the waterproof and anti-root membranes; the protection, filter, and drainage layers; the substrate; and the vegetation. Commercial materials and products available in the market were provided, and innovative materials from recycled sources were analysed [24]. It is possible to use a three-layer concrete slab as a base coat for green roofs. The effectiveness of thermal insulation of a multi-layer, reinforced concrete slab using a layer of concrete with low thermal conductivity and properties of lightweight concrete under the conditions in tropical climates was studied in [25]. The thermal inertia of the extensive green roof in summer conditions was experimentally assessed [26-28].

There are no primary layers on the modular green roof in contrast to the stationary green roof. One of the modular green roof types was proposed by the authors E. Korol and N. Shushunova [29,30]. Planters with plants are placed on the concrete roof's surface [31,32]. Figure 1 shows the principal scheme of the modular green roof.

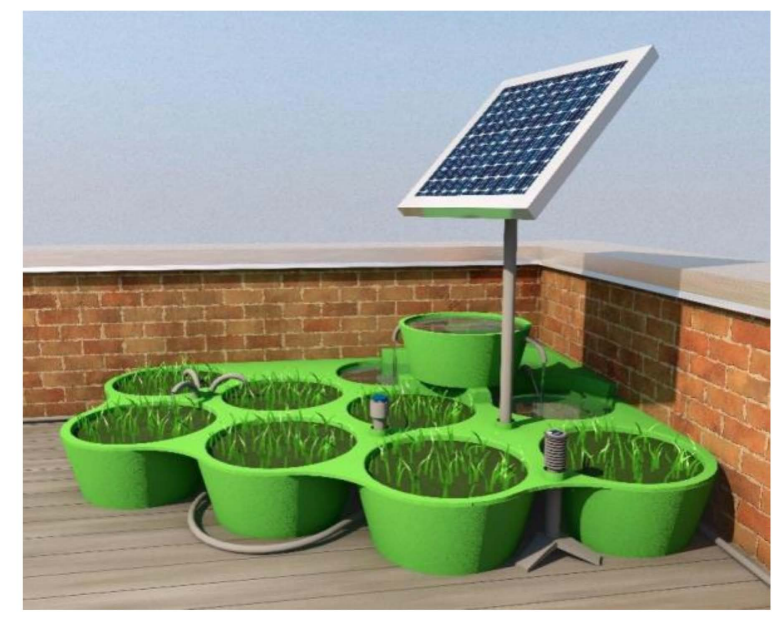

Figure 1. The principal scheme of the modular green roof proposed by the authors [31,32].

The main advantages of modular green roof systems over roll-out green roofs surround convenience and speed of the installation process. Green roof modules can be hand-balled into even the most awkward areas. They can be used to retrofit products for placing on existing conventional roofs [29]. Modular green roofs allow easy and quick replacement of plant pots during the entire life cycle of the roof.

However, no standard assessment methods exist to value green roofs, and balance between different services is lacking [3]. There is still a lack of comprehensive calculation of the economic merit of green roofs and walls, including their installation process, which has restricted the decision-making process [33]. Green roof implementation can be constrained by unsound economic assessment [34].

It follows from the above review that multiphysics processes have not been developed to optimise the technological processes of building green roofs. This study aims to create a spatial-technological model for the proposed modular green roof's installation, based on network planning, scheduling theory, and graph theory. 


\section{Materials and Methods}

The research uses a formalised method for analysis of installing modular green roofs and defines the labour costs of technological processes and operations. The method is based on the principles of saving labour contribution (working hours) and time. Network planning, scheduling theory, and graph theory are used. The formal methods of expert assessment are also included [35].

\section{Results and Discussion}

The following mathematical model was built to calculate installation time and costs and to rationalise the installation organisation. The model of technological processes of the modular green roof installation consists of a spatial-technological model and a functional model (Figure 2).
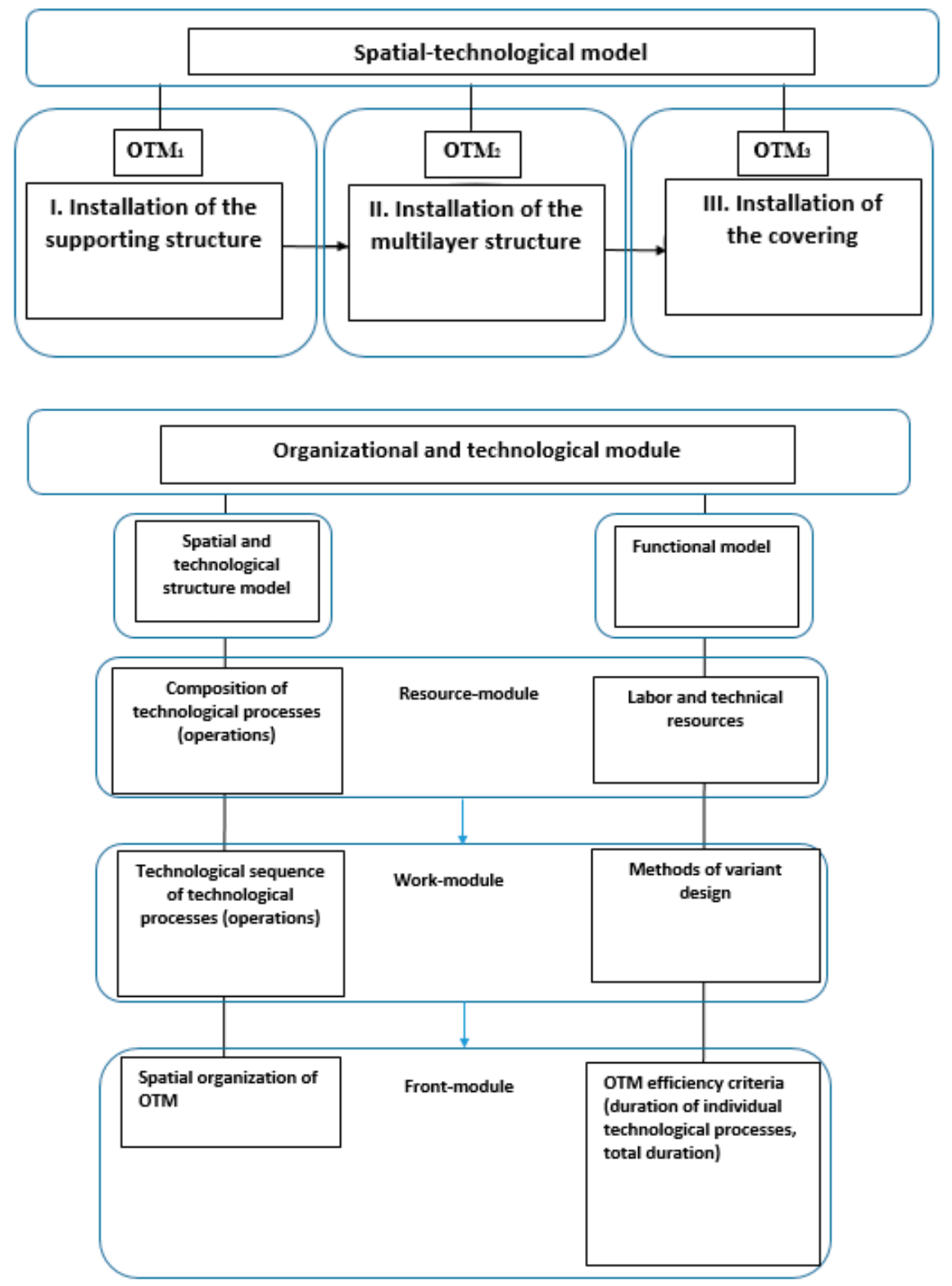

Figure 2. The spatial-technological model and organisational and technological module (OTM).

The spatial-technological model consists of resource modules, front modules, and work modules. The resource module is the technological process's minimum technical (labour) resource for performing a working operation (work module) with a volume equal 
to its shift production. It occupies the necessary working space (front module) for this working operation. These elements make up the organisational and technological modules of individual technological processes of the modular green roof (Figure 2). Organisational modules and technological modules have different physical natures. The model describing all of them is multiphysical.

The installation process was divided into 24 sequential technological operations, listed in Table 1 in the technological sequence of expert assessment [35].

Table 1. The list of technological processes and operations of the organisational and technological module of the device of the modular green roof.

\begin{tabular}{|c|c|c|c|}
\hline $\begin{array}{l}\text { The Name of the } \\
\text { Technological Process } \\
\text { (Technological Operation) }\end{array}$ & $\begin{array}{l}\text { Workers (Profession and } \\
\text { Persons' Number) }\end{array}$ & $\begin{array}{l}\text { Designation of the } \\
\text { Process (Operation) } \\
\text { in the Original List }\end{array}$ & $\begin{array}{l}\text { Redesignation of the } \\
\text { Process (Operation) in the } \\
\text { Technological Sequence }\end{array}$ \\
\hline Preparation of the base & $\begin{array}{l}\text { Roofers of the 2nd category in the } \\
\text { amount of two persons, roofer of the } \\
\text { 3rd category in one person }\end{array}$ & $x_{1}$ & $y_{6}$ \\
\hline $\begin{array}{l}\text { Marking the covering for } \\
\text { laying out the supports } \\
\text { (levelling) }\end{array}$ & $\begin{array}{l}\text { Roofers of the 2nd category in the } \\
\text { amount of two persons, roofer of the } \\
\text { 3rd category in one person }\end{array}$ & $x_{2}$ & $y_{7}$ \\
\hline Layout and gluing of supports & $\begin{array}{l}\text { Roofers of the } 2 \text { nd category in two } \\
\text { persons, roofer of the } 3 \text { rd category in } \\
\text { one person }\end{array}$ & $x_{3}$ & $y_{8}$ \\
\hline Support tilt angle adjustment & $\begin{array}{l}\text { Roofers of the } 2 \text { nd category in two } \\
\text { persons, roofer of the 3rd category in } \\
\text { one person }\end{array}$ & $x_{4}$ & $y_{9}$ \\
\hline Fastening the clips & $\begin{array}{l}\text { Roofers of the } 2 \text { nd category in two } \\
\text { persons, roofer of the } 3 \text { rd category in } \\
\text { one person }\end{array}$ & $x_{5}$ & $y_{10}$ \\
\hline $\begin{array}{l}\text { Laying and fixing the grating } \\
\text { on the supports }\end{array}$ & $\begin{array}{l}\text { Roofers of the } 2 \text { nd category in two } \\
\text { persons, roofer of the 3rd category in } \\
\text { one person }\end{array}$ & $x_{6}$ & $y_{12}$ \\
\hline $\begin{array}{l}\text { Installation and connection of } \\
\text { a group of modules in the } \\
\text { amount of } 4 \text { pcs. fixed to } \\
\text { the gratings }\end{array}$ & $\begin{array}{l}\text { Roofers of the } 2 \text { nd category in two } \\
\text { persons, roofer of the } 3 \text { rd category in } \\
\text { one person }\end{array}$ & $x_{7}$ & $y_{14}$ \\
\hline $\begin{array}{l}\text { Preparation and } \\
\text { transportation of the materials }\end{array}$ & $\begin{array}{l}\text { Riggers of the } 2 \text { nd category in two } \\
\text { persons, driver of the } 4 \text { th category in } \\
\text { one person, driver of the 6th category } \\
\text { in one person, ancillary worker of the } \\
\text { 2nd category in one person }\end{array}$ & $x_{8}$ & $y_{4}$ \\
\hline $\begin{array}{l}\text { Supply of concrete mix } \\
\text { solution in boxes by } \\
\text { truck crane }\end{array}$ & $\begin{array}{l}\text { Riggers of the } 2 \text { nd category in two } \\
\text { persons, driver of the } 4 \text { th category in } \\
\text { one person }\end{array}$ & $x_{9}$ & $y_{13}$ \\
\hline $\begin{array}{l}\text { Transportation of materials } \\
\text { (goods) by hand carts }\end{array}$ & $\begin{array}{l}\text { Ancillary worker of the } 2 \text { nd category in } \\
\text { one person }\end{array}$ & $x_{10}$ & $y_{14}$ \\
\hline $\begin{array}{l}\text { Feeding materials to the roof } \\
\text { by crane }\end{array}$ & $\begin{array}{l}\text { Riggers of the } 2 \text { nd category in two } \\
\text { persons, driver of the } 6 \text { th category in } \\
\text { one person }\end{array}$ & $x_{11}$ & $y_{5}$ \\
\hline Installation of planters & $\begin{array}{l}\text { Roofers of the } 2 \text { nd category in two } \\
\text { persons, ancillary worker of the } 1 \text { st } \\
\text { category in one person }\end{array}$ & $x_{12}$ & $y_{17}$ \\
\hline $\begin{array}{l}\text { Filling a group of modules } \\
\text { with soil and } \\
\text { planting material }\end{array}$ & $\begin{array}{l}\text { Roofers of the } 2 \text { nd category in two } \\
\text { persons, ancillary worker of the 1st } \\
\text { category in one person }\end{array}$ & $x_{13}$ & $y_{19}$ \\
\hline
\end{tabular}


Table 1. Cont.

\begin{tabular}{|c|c|c|c|}
\hline $\begin{array}{c}\text { The Name of the } \\
\text { Technological Process } \\
\text { (Technological Operation) }\end{array}$ & $\begin{array}{l}\text { Workers (Profession and } \\
\text { Persons' Number) }\end{array}$ & $\begin{array}{l}\text { Designation of the } \\
\text { Process (Operation) } \\
\text { in the Original List }\end{array}$ & $\begin{array}{l}\text { Redesignation of the } \\
\text { Process (Operation) in the } \\
\text { Technological Sequence }\end{array}$ \\
\hline $\begin{array}{l}\text { Operational control of the } \\
\text { technological process }\end{array}$ & Master & $x_{14}$ & $y_{18}$ \\
\hline $\begin{array}{l}\text { Incoming inspection } \\
\text { of materials }\end{array}$ & Master & $x_{15}$ & $y_{1}$ \\
\hline $\begin{array}{l}\text { Verification of compliance } \\
\text { with the project arrangement } \\
\text { of roof elements }\end{array}$ & Master & $x_{16}$ & $y_{2}$ \\
\hline $\begin{array}{c}\text { Checking the conformity of } \\
\text { the project of the } \\
\text { incoming materials }\end{array}$ & Master & $x_{17}$ & $y_{3}$ \\
\hline $\begin{array}{l}\text { Quality of preparation of the } \\
\text { coating base }\end{array}$ & Master & $x_{18}$ & $y_{15}$ \\
\hline $\begin{array}{l}\text { Control of the technical } \\
\text { condition of } \\
\text { technological equipment }\end{array}$ & Master & $x_{19}$ & $y_{16}$ \\
\hline $\begin{array}{l}\text { Quality control of finished } \\
\text { joints of structural elements }\end{array}$ & $\begin{array}{l}\text { Laboratory assistant, roofer of the 3rd } \\
\text { category, master }\end{array}$ & $x_{20}$ & $y_{20}$ \\
\hline Visual control & Roofer of the 3rd category & $x_{21}$ & $y_{21}$ \\
\hline $\begin{array}{c}\text { Control of geometric } \\
\text { parameters of roof elements }\end{array}$ & Master & $x_{22}$ & $y_{22}$ \\
\hline $\begin{array}{l}\text { Non-destructive } \\
\text { testing methods }\end{array}$ & Laboratory assistant & $x_{23}$ & $y_{23}$ \\
\hline $\begin{array}{c}\text { Testing of roof structures } \\
\text { and materials }\end{array}$ & Laboratory assistant & $x_{24}$ & $y_{24}$ \\
\hline
\end{tabular}

The algorithm for constructing a spatial and technological structural model was divided into the following stages:

1. Construction of a matrix of technological links of organisational and technological module processes based on the results of an expert assessment of the successionprecedence of technological processes (operations) in paired comparisons.

2. Creation of a graph of the technological sequence based on the matrix data (excluding compound operations).

3. Fragmentation of the graph into specific layers (finding and filtering out paths resulting from the transitivity property).

4. Creation of the final graph of the spatial and technological structure of the organisational and technological module.

First, the technological ordering of the processes and construction of a matrix of technological links of organisational and technological module processes was carried out based on an expert assessment of the succession-precedence of technological processes (operations) in paired comparisons. It is required to find a sequence $Y_{i}$ that is a permutation of the sequence $\mathbf{X}_{\mathbf{i}}$ such that the fact that $\mathbf{Y}_{\mathbf{i}}<<\mathbf{Y}_{\mathbf{j}}$ implies that $i<j$. The " $<<$ " sign was introduced to denote the order in the technological sequence of processes, namely when the sequence $\boldsymbol{X}_{\mathbf{i}}$ precedes the sequence $\boldsymbol{X}_{\mathbf{j}}$.

The conventions for the matrix $\mathbf{X}_{i j}$ elements were introduced to do this ordering. The conventions are as follows:

(1) $X_{i j}=1$ if $X_{i}<<X_{j}$

(2) $X_{i j}=0$ if $X_{j}<<X_{i}$

(3) $X_{i j}=\mathrm{n} / \mathrm{a}$ if condition 1 and condition 2 are not met. 
(4) $\quad X_{i j}=\mathrm{c}$ if one of the elements is an integral part of the other.

(5) $X_{i j}=$ "?" if the relationship between a simple and a composite technological operation cannot be determined.

Figure 3 represents the resulting matrix $\mathbf{X}$ in the form of a technological sequence. The matrix is divided into layers so that all the elements of this layer do not have predecessor works in this, and previous layers and the elements of the first layer do not have predecessor works. The elements of the last one do not have successor works.

\begin{tabular}{|c|c|c|c|c|c|c|c|c|c|c|c|c|c|c|c|c|c|c|c|c|c|c|c|c|}
\hline & $\mathrm{X} 1$ & $\mathrm{X} 2$ & 3 & $\mathrm{X} 4$ & X5 & X6 & X7 & $\mathrm{X} 8$ & \begin{tabular}{|l|}
$x 9$ \\
\end{tabular} & $\mathrm{X} 10$ & $\mathrm{X} 11$ & $\mathrm{X} 12$ & \begin{tabular}{|l|}
$\mathrm{X} 13$ \\
\end{tabular} & $\mathrm{X} 14$ & $\mathrm{X} 15$ & $\mathrm{X} 16$ & $\mathrm{X} 17$ & $\mathrm{X} 18$ & $\mathrm{X} 19$ & $\mathrm{X} 20$ & $\mathrm{X} 21$ & $\mathrm{X} 22$ & $\mathrm{X} 23$ & $x$ \\
\hline $\mathrm{x} 1$ & 0 & & $c$ & & & c & & $\mathrm{n} / \mathrm{a}$ & $\mathrm{n} / \mathrm{a}$ & $n / a$ & $\mathrm{n} / \mathrm{a}$ & 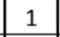 & 1 & $\mathrm{n} / \mathrm{a}$ & 0 & ? & 0 & 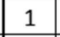 & 1 & 1 & 1 & 1 & 1 & 1 \\
\hline$x 2$ & c & 0 & $\mathrm{n} / \mathrm{a}$ & n/a & n/ & 1 & 1 & & $\mathrm{n} / \mathrm{a}$ & & n & & & & & 0 & & & $\mathrm{n} / \mathrm{a}$ & & & & & \\
\hline X3 & c & $\mathrm{n} / \mathrm{a}$ & $\begin{array}{ll}0 \\
\end{array}$ & a & f & & & $\mathrm{a}$ & $\mathrm{n} / \mathrm{a}$ & a & 1 & & & $n / 2$ & & $\mathrm{n} / \mathrm{a}$ & & & & & & & & \\
\hline X4 & $c$ & a) & $\mathrm{n} / \mathrm{a}$ & \begin{tabular}{|l|}
0 \\
\end{tabular} & la & & & a & n/a & & & & & 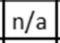 & & & n/a & & $/ \mathrm{a}$ & & & & & \\
\hline X5 & c & $\mathrm{n} / \mathrm{a}$ & $\mathrm{n} / \mathrm{a}$ & $\mathrm{n} / \mathrm{a}$ & 0 & 1 & 1 & $\mathrm{a}$ & $\mathrm{n} / \mathrm{a}$ & & $\mathrm{n} / \mathrm{a}$ & & & 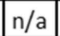 & & & $\mathrm{n} / \mathrm{a}$ & & & & & & & 1 \\
\hline $\mathrm{X} 6$ & 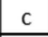 & 0 & 0 & & 0 & 0 & 1 & a & $\mathrm{n} / \mathrm{a}$ & $\mathrm{n} / \mathrm{a}$ & $n$ & - & & & I & $\mathrm{n} / \mathrm{a}$ & $\mathrm{n} / \mathrm{a}$ & & & & & & & \\
\hline$x$ & c & 0 & 0 & & 0 & 0 & 0 & & 0 & 0 & & 1 & & $\mathrm{n} / \mathrm{a}$ & 0 & 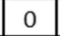 & 0 & $\mathrm{n} / \mathrm{a}$ & $n / a$ & & 1 & & 1 & 1 \\
\hline$x 8$ & c & $\mathrm{n} / \mathrm{a}$ & $\mathrm{n} / \mathrm{a}$ & $\mathrm{n} / \mathrm{a}$ & $\mathrm{n} / \mathrm{a}$ & $\mathrm{n} /$ & 1 & c & 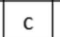 & & & 1 & & $\mathrm{n} / \mathrm{a}$ & $\mathrm{n} / \mathrm{a}$ & $\mathrm{n} / \mathrm{a}$ & $\mathrm{n} / \mathrm{a}$ & $\mathrm{n}$ & & & & & & 1 \\
\hline $\mathrm{X9}$ & & & $\mathrm{n} / \mathrm{a}$ & & 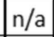 & & 1 & & ( & & & & & & & n & & & & & & & & \\
\hline X10 & $\mathrm{n} / \mathrm{a}$ & & n/a & 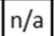 & a & & 1 & c & & & & & & $n / a$ & $\mathrm{n} / \mathrm{a}$ & $\mathrm{n} / \mathrm{a}$ & & & & & & & & 1 \\
\hline $\mathrm{X} 11$ & n/a & $\mathrm{n} / \mathrm{a}$ & $n / a$ & n/a & n/a & n, & 1 & $c$ & 1 & & 0 & 1 & 1 & $\mathrm{n} / \mathrm{a}$ & $\mathrm{n} / \mathrm{a}$ & $\mathrm{n} / \mathrm{a}$ & $\mathrm{n} / \mathrm{a}$ & $\mathrm{n} / \mathrm{a}$ & & & & & 1 & 1 \\
\hline $\mathrm{X} 12$ & 0 & 0 & 0 & 0 & \begin{tabular}{|l|} 
\\
\end{tabular} & 0 & 0 & 0 & c & c & C & 0 & c & $\mathrm{n} / \mathrm{a}$ & 0 & 0 & 0 & 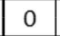 & & & & 1 & 1 & 1 \\
\hline X13 & 0 & 0 & 0 & 0 & c & c & 0 & 0 & 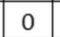 & & 0 & & 0 & $\mathrm{n} /$ & & $c$ & & & & & & & 1 & 1 \\
\hline $\mathrm{X} 14$ & $n / a$ & $\mathrm{n} / \mathrm{a}$ & n/a & n/a & n/a & n/a & n/a & $\mathrm{n} / \mathrm{a}$ & 0 & $\mathrm{n} / \mathrm{a}$ & $\mathrm{n} / \mathrm{a}$ & $\mathrm{n} / \mathrm{a}$ & $\mathrm{n} / \mathrm{a}$ & & & $c$ & & & & & & & 1 & 1 \\
\hline X15 & 1 & 1 & 1 & 1 & 1 & 1 & 1 & $\mathrm{n} / \mathrm{a}$ & c & d & $\mathrm{n} / \mathrm{a}$ & & & & & c & & 1 & $n / a$ & & 1 & 1 & 1 & 1 \\
\hline $\mathrm{X} 1$ & & 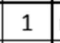 & $\mathrm{n} / \mathrm{a}$ & 1 & 1 & $\mathrm{n} / \mathrm{a}$ & 1 & n/a & n/a & $\mathrm{n} / \mathrm{a}$ & $\mathrm{n} / \mathrm{a}$ & & 1 & & $c$ & 0 & $\mathrm{n} / \mathrm{a}$ & n/a & $\mathrm{n} / \mathrm{a}$ & 1 & 1 & 1 & 1 & 1 \\
\hline $\mathrm{X} 1$ & & 1 & 1 & n/a & $\mathrm{n} / \mathrm{a}$ & $\mathrm{n} / \mathrm{a}$ & 1 & $\mathrm{n} / \mathrm{a}$ & 1 & & $\mathrm{n} / \mathrm{a}$ & 1 & & & $c$ & $\mathrm{n} / \mathrm{a}$ & 0 & $\mathrm{n} / \mathrm{a}$ & 1 & 1 & 1 & 1 & 1 & 1 \\
\hline $\mathrm{X} 1$ & 0 & 0 & 0 & 0 & 0 & \begin{tabular}{|l|} 
\\
\end{tabular} & $n / a$ & n/a & n/a & $\mathrm{n} / \mathrm{a}$ & n/a & & & & & $n / a$ & $n / a$ & 0 & $\mathrm{n} / \mathrm{a}$ & & 1 & 1 & 1 & 1 \\
\hline $\mathrm{X} 1$ & 0 & $\mathrm{n} / \mathrm{a}$ & 0 & n/a & 0 & 0 & $\mathrm{n} / \mathrm{a}$ & 0 & 0 & & 0 & & 1 & & $\mathrm{n} / \mathrm{a}$ & $\mathrm{n} / \mathrm{a}$ & 0 & $\mathrm{n} / \mathrm{a}$ & & & 1 & 1 & 1 & 1 \\
\hline $\mathrm{x} 2$ & 0 & 0 & c & 0 & c & 0 & 0 & ( & & & & & c & & & & & & & 0 & $n / a$ & $a_{1}$ & n/a & $1 / a$ \\
\hline X21 & c & 0 & 0 & 0 & c & c & 0 & c & & & - & & 0 & & & 0 & & 0 & & $\mathrm{a}$ & 0 & $\mathrm{n} / \mathrm{a}$ & $\mathrm{n} / \mathrm{a}$ & $\mathrm{n} / \mathrm{a}$ \\
\hline$x 2$ & 0 & 0 & 0 & 0 & 0 & 0 & 0 & 0 & $c$ & c & 0 & 0 & 0 & 0 & 0 & 0 & 0 & 0 & 0 & a & n/a & 0 & n/a & $\mathrm{n} / \mathrm{a}$ \\
\hline$x 2$ & 0 & 0 & 0 & c & 0 & 0 & 0 & c & c & 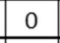 & c & & $c$ & & ( & & & & & & n/a & $n / a$ & 0 & n/a \\
\hline $2-1$ & 0 & 0 & 0 & 0 & 0 & 0 & 0 & 0 & 0 & & 0 & 0 & 0 & & & & & & 0 & $n / a$ & n/a & $\mathrm{n} / \mathrm{a}$ & n/a & 0 \\
\hline
\end{tabular}

Figure 3. The matrix of technological links of individual technological processes (operations) of the device of the modular green roof.

The following algorithm was introduced for this division:

- $\quad$ All the rows of the matrix that satisfy the condition: $i \neq j, X_{i j} \neq 0$ are found.

- The elements $X_{i j} \neq 0$ are replaced in the first layer of the row in which they are found.

- Elements $X_{i j}$ belonging to the next layer are found. It is necessary to find such rows $\mathbf{X}_{i}$ that $i \neq j, X_{i j}=0$ implies that the row $\mathbf{X}_{i}$ is contained in the set of layers from the first layer to the layer under consideration.

This algorithm for fragmentation of the graph into layers is finished when all rows $\mathbf{X}_{i}$ that do not contain ones are found.

Figure 4 shows the results as a graph of the technological structure of the organisational and technological module with fragmentation into layers so that the processes (operations) are technologically independent. Hence, the processes (operations) can be performed in parallel. 


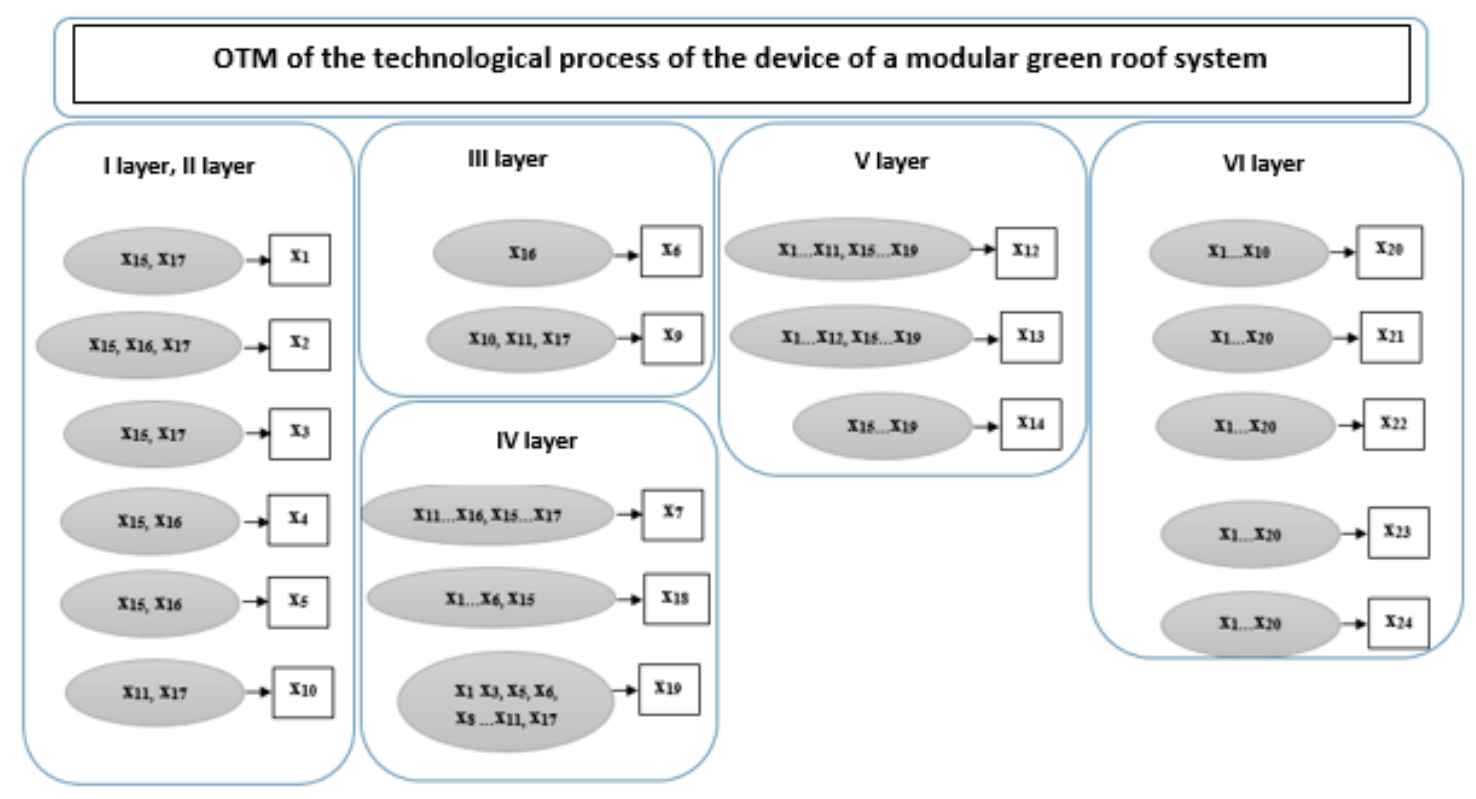

Figure 4. The graph of the technological structure of the organisational and technological module (OTM) of the technological process of the device of the modular green roof.

The constructed graph indicates technological operations in the form of elements $X_{i j}$ of the matrix. The arrows show the technological connections between operations. Based on the constructed graph, the following can be established:

(1) Technological operation $X_{15}$ is composite.

(2) It includes operations $X_{9}, X_{16}, X_{17}$, which may be present in any of 1-3 layers.

(3) Technological operation $X_{14}$ is not composite. It may be executed in parallel with operation $\mathrm{X}_{12}$.

(4) Based on the results of constructing the graph, the cycles are eliminated.

After constructing the graph, a new list of technological processes and operations of organisational and technological modules for the green roof was compiled, indicating the workplaces of the work. The technological operations are numbered in this list based on their technological sequence. In the graph, simple technological operations that are not a part of others begin with the capital letter " $Y$ " and compound operations with the lowercase " $y$ ". As a result of these operations' spatial and technological ordering based on network planning methods, a model (graph) of the "top-work" type was formed (Figure 5).

The " = =" sign was introduced to denote the relationship of spatial equivalence. The rule of the denotation is as follows: if $Y_{i}, Y_{j} \in Y_{i} \& k_{i}=k_{j}$, then $Y_{i}==Y_{j}$. This relation is reflected in the graph of the spatial structure of the technological process. Connections of spatial equivalence were established in the places where it is possible to perform them in a specific subspace. There,

$k_{1}$ is the main subspace, i.e., the class of spatial equivalence of the working area of the roofing device (connections between operations performed in the working area);

$k_{2}$ is the class of spatial equivalence: site of acceptance and preparation of materials (serving subspace); and

$k_{3}$ is the spatial equivalence class of the testing laboratory (serving subspace).

Then, a graph of resource equivalence of a roofing device with modular landscaping is built (Figure 6), and the performers of technological processes and operations are assigned the corresponding numbers-resource equivalence classes (l):

$l_{1}$ is the labour resource equivalence of the class: master in the amount of one person;

$l_{2}$ is the labour resource equivalence of the class: rigger of the second category in the amount of two persons, driver of the sixth category in the amount of one person; 
$l_{3}$ is the resource equivalence class: ancillary worker of the second category in the amount of one person;

$l_{4}$ is the resource equivalence class: roofer of the second category in the amount of two persons, roofer of the third category in the amount of one person; and

$l_{5}$ is the resource equivalence class: laboratory assistant in the amount of one person.

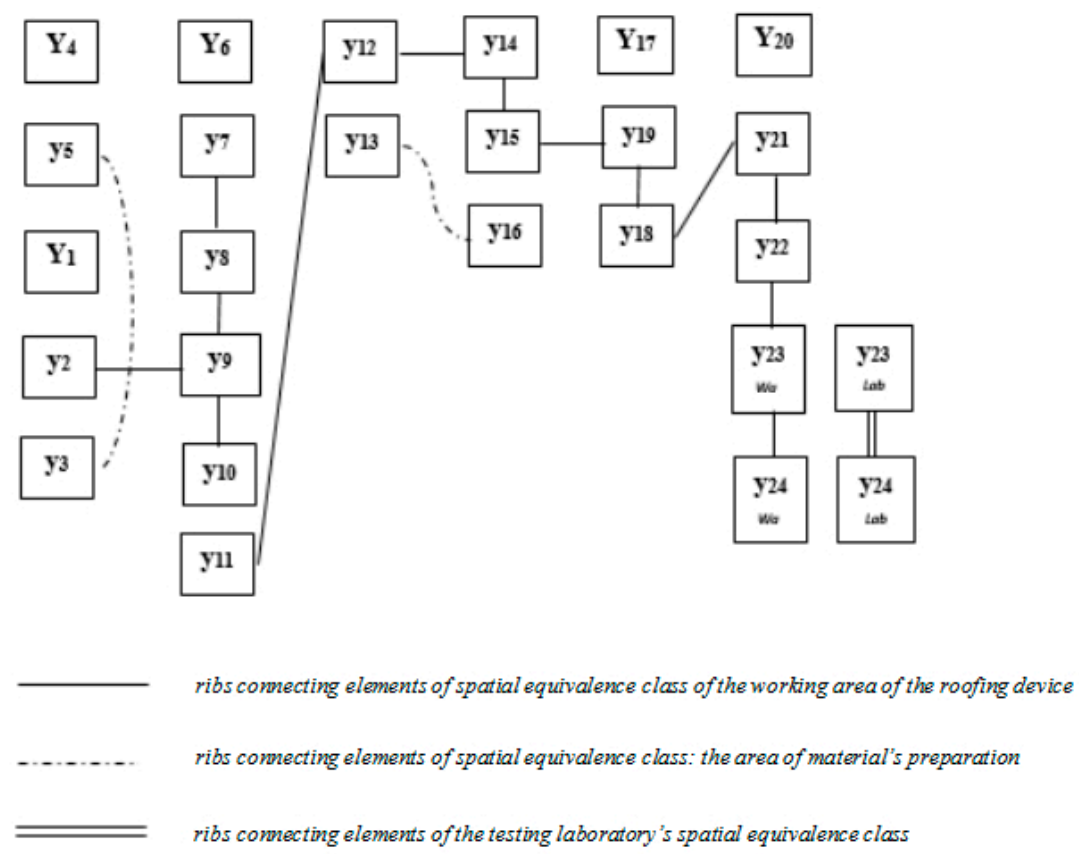

Figure 5. The graph of the spatial structure of the organisational and technological modules. Waworking area; Lab-testing laboratory.
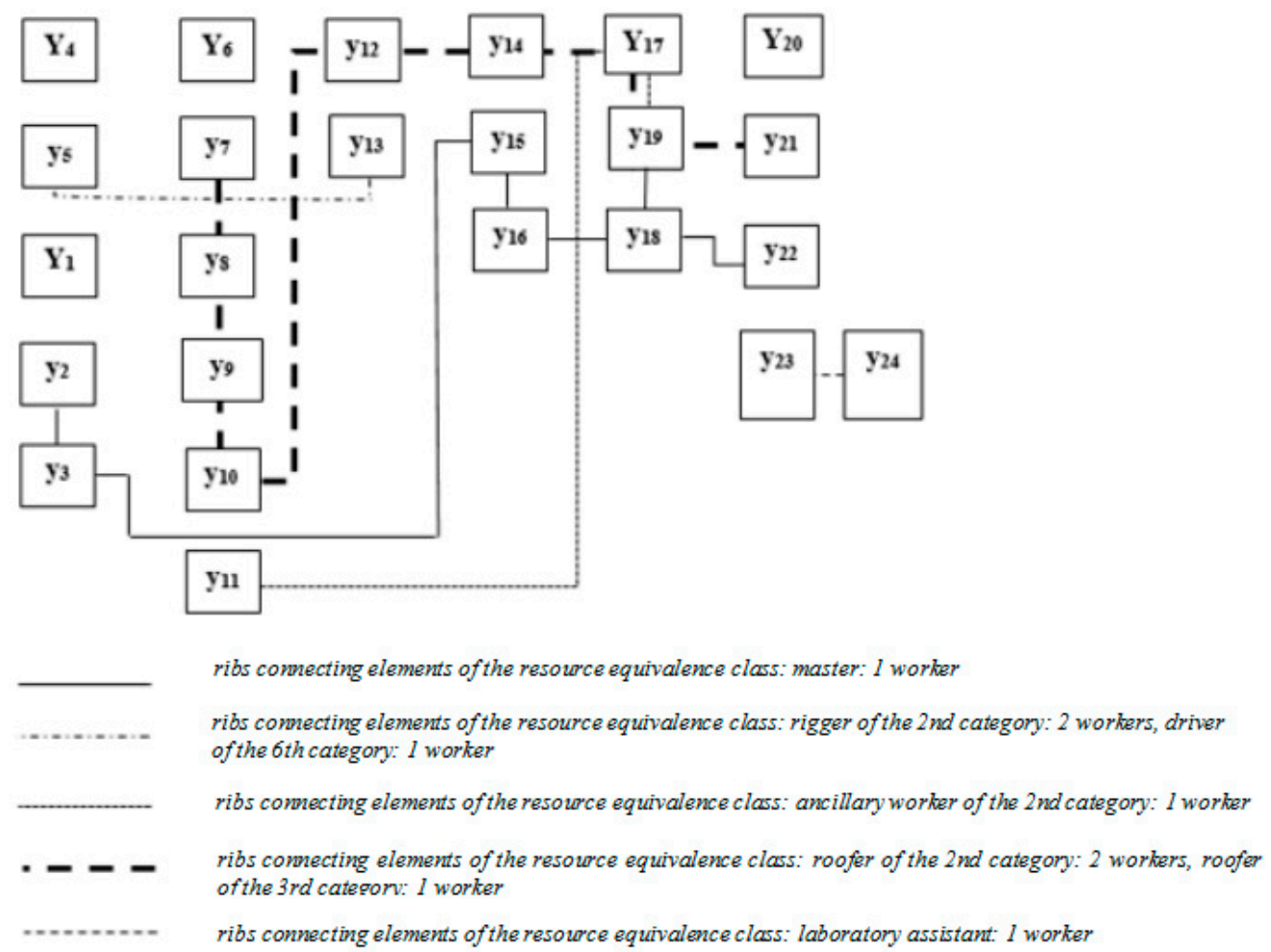

Figure 6. The graph of the distribution of labour resources of the organisational and technological module of the technological process of the device of a modular roof. 
Classes of spatial equivalence $k$ and classes of resource equivalence $l$ are introduced to assess technological operations that can be performed in parallel (up to the front module).

The organisational and technological module was developed after the spatial and technological structure were constructed and the technological and spatial ordering of technological processes were formed.

In the functional model, for each technological process (technological operation), the value of its execution time $t_{i j k l}$ is introduced, where:

$i$ is the index of the sequence element (operation number), $i=1,2, \ldots 24$;

$j$ is the number of the layer in which the operation is located, $j=1,2, \ldots 6$;

$k$ is the number of the main or serving subspace, $k=1,2,3$; and

$l$ is the number (class) of the labour resource, $i=1,2, \ldots 5$.

In this case, the value $t_{i j k l}$ can be unambiguously replaced by the value $t_{1}$ as $t_{i j k l}=t_{1}$ (Figure 7).

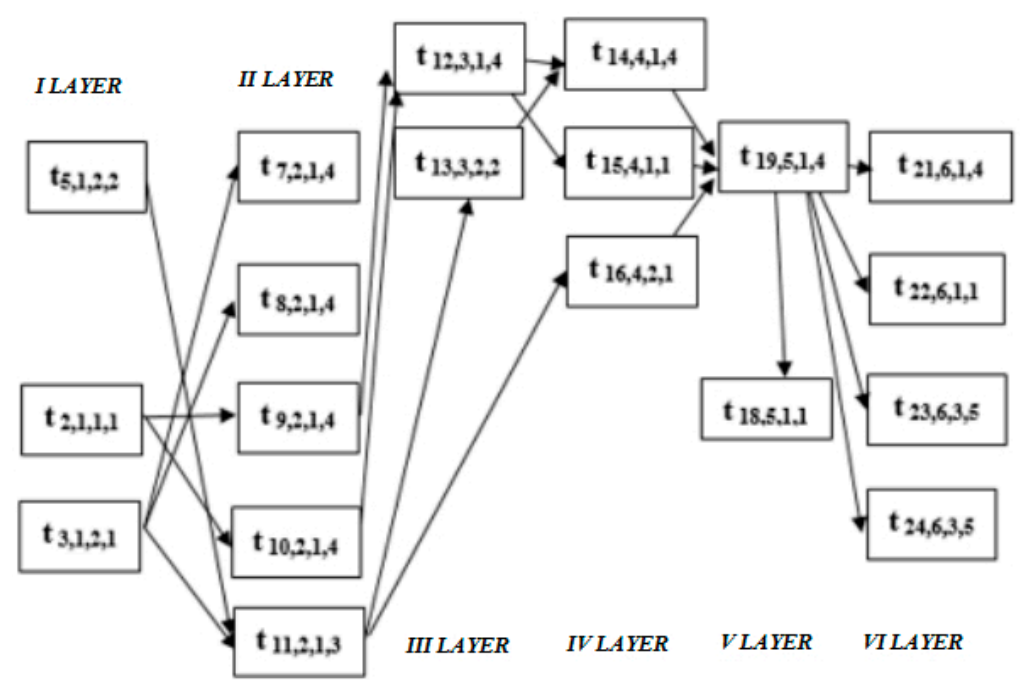

Figure 7. The graph of the functional model of the organisational and technological module.

With the formed structural and functional model, the total duration of the operations of the main subspace of the organisational and technological module is found according to the formula:

$$
T_{\text {OTM }}=\sum_{j=1}^{7} f\left(t_{i_{n}, j, k, l_{n}}, f\left(t_{i_{n-1}, j, k, l n-1}, f\left(t_{i_{2}, j, k, l_{2}}\right)\right) \ldots\right)
$$

where $n$ for each $j$ is the number of elements in the layer,

$$
\left(t_{i_{n}, j, k, l_{n}}, t_{i_{n}, j, k, l_{n}}\right)=\left\{\begin{array}{cl}
t_{i_{n}, j, k, l_{n}}+t_{i_{n}, j, k, l_{n},} & \text { if } l_{1}=l_{2}(\text { sequential work of one resource) } \\
\max \left(t_{i_{n}, j, k, l_{n}} \cdot t_{i_{n}, j, k, l_{n}}\right), & \text { if } l_{1} \neq l_{2} \text { (parallel work on two resources) }
\end{array}\right.
$$

The duration of work in the main subspace is decisive for the remaining subspaces and adjacent processes. Therefore, work operations in the serving subspaces can begin at earlier times than in the main subspace.

Thus, creating the structural-functional model makes it possible to determine the main indicators of the organisational efficiency of installing the modular green roof.

\section{Conclusions}

The research object is the installation process of modular green roofs with planters placed on the concrete roof's surface. These roofs effectively reduce rainfall disposal, increase the prolonged lifespan of the roof coating, and enhance urban aesthetic and recreational spaces. Green roofs reduce houses' gas emissions and increase green spaces in densely built areas. 
One of the modular green roof types was proposed by the authors E. Korol and N. Shushunova $[29,30]$. However, no standard assessment methods exist to value green roofs, and balance between different services is lacking [3]. There is still a lack of comprehensive calculation of the economic merit of green roofs and walls, including their installation process, which has restricted the decision-making process [33]. Green roof implementation can be constrained by unsound economic assessment [34].

The spatial-technological model was developed for the proposed modular green roof based on network planning, scheduling theory, and graph theory. Analysing the model led to the following conclusions:

(1) The sequence and composition of technological processes and operations was established for installing the modular green roof.

(2) The spatial and technological structure model has been built as a result of the formation of technological and spatial ordering of technological processes.

(3) The functional model of installing a modular green roof has been developed. The model makes it possible to optimise on the principles of saving labour contribution (working hours) and time.

Author Contributions: Conceptualisation, N.S.S., E.A.K., and N.I.V.; methodology, N.S.S. and E.A.K.; validation, N.S.S. and E.A.K.; formal analysis, N.S.S.; investigation, N.S.S. and E.A.K..; resources, N.S.S., E.A.K., and N.I.V.; data curation, N.S.S. and E.A.K.; writing—original draft preparation, N.S.S. and E.A.K.; writing—review and editing, N.I.V.; supervision, E.A.K.; project administration, E.A.K.; funding acquisition, N.I.V. All authors have read and agreed to the published version of the manuscript.

Funding: The research is partially funded by the Ministry of Science and Higher Education of the Russian Federation as part of the World-class Research Center program: Advanced Digital Technologies (contract No. 075-15-2020-934 dated 17 November 2020).

Institutional Review Board Statement: Not applicable.

Informed Consent Statement: Not applicable.

Data Availability Statement: The data presented in this study are available on request from the corresponding author.

Conflicts of Interest: The authors declare no conflict of interest.

\section{References}

1. Bevilacqua, P. The effectiveness of green roofs in reducing building energy consumptions across different climates. A summary of literature results. Renew. Sustain. Energy Rev. 2021, 151, 111523. [CrossRef]

2. Hanumesh, M.; Claverie, R.; Séré, G. A roof of greenery, but a sky of unexplored relations-Meta-analysis of factors and properties that affect green roof hydrological and thermal performances. Sustainability 2021, 13, 10017. [CrossRef]

3. Liu, H.; Kong, F.; Yin, H.; Middel, A.; Zheng, X.; Huang, J.; Xu, H.; Wang, D.; Wen, Z. Impacts of green roofs on water, temperature, and air quality: A bibliometric review. Build. Environ. 2021, 196, 107794. [CrossRef]

4. Knight, T.; Price, S.; Bowler, D.; Hookway, A.; King, S.; Konno, K.; Richter, R.L. How effective is 'greening' of urban areas in reducing human exposure to ground-level ozone concentrations, UV exposure and the 'urban heat island effect'? An updated systematic review. Environ. Evid. 2021, 10, 1-38. [CrossRef]

5. Priya, U.K.; Senthil, R. A review of the impact of the green landscape interventions on the urban microclimate of tropical areas. Build. Environ. 2021, 205, 108190. [CrossRef]

6. Gorshkov, A.S.; Vatin, N.I.; Rymkevich, P.P. Climate change and the thermal island effect in the million-plus city. Constr. Unique Build. Struct. 2020, 89, 8902. [CrossRef]

7. Parsaee, M.; Joybari, M.M.; Mirzaei, P.A.; Haghighat, F. Urban heat island, urban climate maps and urban development policies and action plans. Environ. Technol. Innov. 2019, 14, 100341. [CrossRef]

8. Jamei, E.; Chau, H.W.; Seyedmahmoudian, M.; Stojcevski, A. Review on the cooling potential of green roofs in different climates. Sci. Total Environ. 2021, 791, 148407. [CrossRef]

9. Liu, Z.; Cheng, W.; Jim, C.Y.; Morakinyo, T.E.; Shi, Y.; Ng, E. Heat mitigation benefits of urban green and blue infrastructures: A systematic review of modeling techniques, validation and scenario simulation in ENVI-met V4. Build. Environ. 2021, 200, 107939. [CrossRef] 
10. Wong, N.H.; Tan, C.L.; Kolokotsa, D.D.; Takebayashi, H. Greenery as a mitigation and adaptation strategy to urban heat. Nat. Rev. Earth Environ. 2021, 2, 166-181. [CrossRef]

11. Krayenhoff, E.S.; Broadbent, A.M.; Zhao, L.; Georgescu, M.; Middel, A.; Voogt, J.A.; Martilli, A.; Sailor, D.J.; Erell, E. Cooling hot cities: A systematic and critical review of the numerical modelling literature. Environ. Res. Lett. 2021, 16, 053007. [CrossRef]

12. Liu, T.; Lawluvy, Y.; Shi, Y.; Yap, P.-S. Low Impact Development (LID) Practices: A Review on Recent Developments, Challenges and Prospects. Water. Air Soil Pollut. 2021, 232, 1-36. [CrossRef]

13. Adem Esmail, B.; Suleiman, L. Analyzing Evidence of Sustainable Urban Water Management Systems: A Review through the Lenses of Sociotechnical Transitions. Sustainability 2020, 12, 4481. [CrossRef]

14. Hachoumi, I.; Pucher, B.; De Vito-Francesco, E.; Prenner, F.; Ertl, T.; Langergraber, G.; Fürhacker, M.; Allabashi, R. Impact of Green Roofs and Vertical Greenery Systems on Surface Runoff Quality. Water 2021, 13, 2609. [CrossRef]

15. Statistical Review of World Energy 2021 by British Petroleum. Available online: https://www.bp.com/content/dam/bp/ business-sites/en/global/corporate/pdfs/energy-economics/statistical-review/bp-stats-review-2021-full-report.pdf (accessed on 29 October 2021).

16. Rafael, S.; Correia, L.P.; Ascenso, A.; Augusto, B.; Lopes, D.; Miranda, A.I. Are green roofs the path to clean air and low carbon cities? Sci. Total Environ. 2021, 798, 149313. [CrossRef]

17. Seyedabadi, M.R.; Eicker, U.; Karimi, S. Plant selection for green roofs and their impact on carbon sequestration and the building carbon footprint. Environ. Chall. 2021, 4, 100119. [CrossRef]

18. Nadeeshani, M.; Ramachandra, T.; Gunatilake, S.; Zainudeen, N. Carbon Footprint of Green Roofing: A Case Study from Sri Lankan Construction Industry. Sustainability 2021, 13, 6745. [CrossRef]

19. Trovato, M.R.; Nocera, F.; Giuffrida, S. Life-Cycle Assessment and Monetary Measurements for the Carbon Footprint Reduction of Public Buildings. Sustainability 2020, 12, 3460. [CrossRef]

20. Joshi, M.Y.; Teller, J. Urban Integration of Green Roofs: Current Challenges and Perspectives. Sustainability 2021, $13,12378$. [CrossRef]

21. Hirano, Y.; Ihara, T.; Gomi, K.; Fujita, T. Simulation-Based Evaluation of the Effect of Green Roofs in Office Building Districts on Mitigating the Urban Heat Island Effect and Reducing $\mathrm{CO}_{2}$ Emissions. Sustainability 2019, 11, 2055. [CrossRef]

22. Balaban, O.; Puppim de Oliveira, J.A. Sustainable buildings for healthier cities: Assessing the co-benefits of green buildings in Japan. J. Clean. Prod. 2017, 163, S68-S78. [CrossRef]

23. Shafique, M.; Luo, X.; Zuo, J. Photovoltaic-green roofs: A review of benefits, limitations, and trends. Sol. Energy 2020, $202,485-497$. [CrossRef]

24. Cascone, S. Green roof design: State of the art on technology and materials. Sustainability 2019, 11, 3020. [CrossRef]

25. Halwatura, R.U.; Jayasinghe, M.T.R. Thermal performance of insulated roof slabs in tropical climates. Energy Build. 2008, 40, 1153-1160. [CrossRef]

26. Bevilacqua, P.; Mazzeo, D.; Arcuri, N. Thermal inertia assessment of an experimental extensive green roof in summer conditions. Build. Environ. 2018, 131, 264-276. [CrossRef]

27. Abdo, P.; Huynh, B.P.; Irga, P.J.; Torpy, F.R. Evaluation of air flow through an active green wall biofilter. Urban For. Urban Green. 2019, 41, 75-84. [CrossRef]

28. Bevilacqua, P.; Mazzeo, D.; Bruno, R.; Arcuri, N. Surface temperature analysis of an extensive green roof for the mitigation of urban heat island in southern mediterranean climate. Energy Build. 2017, 150, 318-327. [CrossRef]

29. Korol, E.; Shushunova, N. Benefits of a Modular Green Roof Technology. Procedia Eng. 2016, 161, 1820-1826. [CrossRef]

30. Korol, O.; Shushunova, N.; Lopatkin, D.; Zanin, A.; Shushunova, T. Application of High-tech Solutions in Ecodevelopment. MATEC Web Conf. 2018, 251, 06002. [CrossRef]

31. Korol, E.; Shushunova, N. Green Roofs: Standardization and Quality Control of Processes in Green Construction. In Proceedings of the MATEC Web of Conferences, Taichung, Taiwan, 28 October-1 November 2017; Volume 106.

32. Korol, E.; Shushunova, N. Research and Development for the International Standardization of Green Roof Systems. Procedia Eng. 2016, 153, 287-291. [CrossRef]

33. Teotónio, I.; Silva, C.M.; Cruz, C.O. Economics of green roofs and green walls: A literature review. Sustain. Cities Soc. 2021, 69, 102781. [CrossRef]

34. Zhang, G.; He, B.-J. Towards green roof implementation: Drivers, motivations, barriers and recommendations. Urban For. Urban Green. 2021, 58, 126992. [CrossRef]

35. Korol, O.A. Development of the methodology of calendar planning in the system of organizational and technological preparation of capital repair of multi-apartment residential houses. J. Phys. Conf. Ser. 2019, 1425, 012086. [CrossRef] 